\title{
The physiology, pharmacology and therapeutic manipulation of the internal anal sphincter
}

\author{
Oliver M Jones MA FRCS ${ }^{1,2}$, Alison F Brading BSc PhD ${ }^{1}$, \\ Neil J McC Mortensen MD FRCS ${ }^{2}$
}

OM Jones, AF Brading, NJMcC Mortensen. The physiology, pharmacology and therapeutic manipulation of the internal anal sphincter. Can J Gastroenterol 2002;16(4):249-257.

Recent research into the physiology and pharmacology of the internal anal sphincter has elucidated the importance of this structure in health and disease. Its pharmacological manipulation for therapeutic gain has focused mainly on agents to reduce internal anal sphincter tone, a 'chemical sphincterotomy' that might heal chronic anal fissure. However, drugs to increase sphincter tone, and augment intermittent and appropriate relaxation are also being evaluated. The initial results with this medical approach to anorectal disease have often been disappointing, failing to match the results achievable with surgery, and many of these drugs have a high rate of side effects in the short term. However, clinical trials have yet to establish the optimum doses, dose intervals and routes of administration for many of these therapies. Furthermore, it is uncertain whether this medical approach should be applied to all patients or just to an as yet undefined subgroup. Certainly, even in the current environment of uncertainty, there is little reason not to try medical manipulation of the internal sphincter as first-line treatment. Surgery remains an option for treatment failures; patients responding to pharmacological manipulation of the internal anal sphincter are spared the long term risks of continence that are inherent in many surgical procedures on the anorectum.

Key Words: Anal fissure; Anal sphincter; Fecal incontinence

\section{La physiologie, la pharmacologie et la manipulation thérapeutique du spincter anal interne}

RÉSUMÉ : Les recherches récentes sur la physiologie et la pharmacologie du sphincter anal interne ont permis d'élucider l'importance de cette structure dans la santé et la maladie. Sa manipulation pharmacologique pour obtenir une amélioration thérapeutique a surtout été axée sur des agents pour réduire le tonus du sphincter anal interne, une « sphincterotomie chimique " susceptible de guérir des fissures anales chroniques. Cependant, les médicaments visant à accroître le tonus sphinctérien et à favoriser une relaxation intermittente et pertinente sont également en voie d'évaluation. Les résultats initiaux de cette démarche sur les maladies anorectales sont souvent décevants, car ils ne donnent pas les résultats qu'il est possible d'obtenir par intervention chirurgicale, et bon nombre de ces médicaments ont un taux élevé d'effets secondaires à court terme. Cependant, dans plusieurs de ces traitements, les essais cliniques n'ont pas encore permis d'établir les doses optimales, les intervalles entre les doses et les voies d'administration. De plus, on ne sait pas si cette démarche médicale doit être appliquée à tous les patients ou seulement à un sousgroupe encore mal défini. Quoi qu'il en soit, même dans le climat d'incertitude actuel, rien n'empêche d'essayer la manipulation médicale du sphincter comme traitement de première ligne. L'opération demeure une possibilité en cas d'échec du traitement, mais les patients qui réagissent à la manipulation pharmacologique du sphincter anal interne évitent les risques à long terme reliés à la continence, inhérents à de nombreuses interventions anorectales.

${ }^{1}$ Department of Pharmacology, Mansfield Road and ${ }^{2}$ Department of Colorectal Surgery, John Radcliffe Hospital, Oxford, United Kingdom Correspondence: Dr Oliver Jones, Department of Pharmacology, Mansfield Road, Oxford, United Kingdom OX1 3QT.

Telephone+00441865-271878, fax+00441865-271853, e-mail oliver.jones@pharm.ox.ac.uk

Received for publication May 22, 2001. Accepted November 28, 2001 
$\mathrm{T}$ he anal sphincter musculature is central to the maintenance of continence, but continence is not determined solely by its structure and function. It is dependent on many other factors, including stool composition, anorectal sensation and colonic motility. Patient perception and coping strategies determine the impact on quality of life. Some individuals, though almost perfectly continent by any objective measure, are socially crippled by the fear of 'accidents'.

Recent research into the physiology and pharmacology of the internal anal sphincter (IAS) has laid the foundation for attempts to modify IAS function with drug therapy. Although still in its infancy, pharmacological therapy of benign anorectal disease has the potential to alter the approach to these conditions in much the same way as the $\mathrm{H}_{2}$ receptor antagonists and proton pump inhibitors have affected surgery of the upper gastrointestinal tract.

The present review begins with a summary of the current understanding of the basic physiology and pharmacology of the IAS. This knowledge has been used as the basis for the pharmacological reduction and augmentation of anal canal pressure, and success in these areas is examined. Finally, as a glimpse into the future, the challenge of intermittent but appropriate sphincter relaxation is examined.

\section{PHYSIOLOGICAL CONSIDERATIONS}

Over 80 years ago, it was proposed that the IAS received an excitatory sympathetic innervation and an inhibitory parasympathetic innervation (1). Although this arrangement differs from that of most of the rest of the gastrointestinal tract, it is duplicated in other sphincters, including that of the urethra. The sympathetic input (from the thoracolumbar spinal cord) comes predominantly via the hypogastric plexus, while the parasympathetic input (S1-3) relays in the pelvic plexus.

The enteric nervous system, often described as the third division of the autonomic nervous system, is responsible for the gastrointestinal functions seen after sectioning of extrinsic nerves (2). This enteric nervous system comprises two plexi of ganglia: Auerbach's (myenteric) plexus and Meissner's (submucous) plexus. It is responsible for the peristaltic contractions of the gut and also mediates entire reflex pathways.

Local anesthetic blockade of the pudendal nerves demonstrates that the smooth muscle IAS is responsible for between $50 \%$ and $85 \%$ of resting anal tone (3). The striated, voluntary, external anal sphincter makes a greater contribution during periods of rectal distension. The tone of the IAS is due to both intrinsic myogenic tone and extrinsic sympathetic innervation $(4,5)$. That there is a tonic discharge of sympathetic nerves maintaining anal canal pressure can be demonstrated by effecting sympathetic blockade by either high spinal anesthesia (6) or infusion of the alpha-adrenoceptor antagonist phentolamine (7). Both cause reductions in anal canal pressure of around $50 \%$. The effects of presacral nerve stimulation at operation have been shown to induce both a fall and rise in anal canal pressure $(8,9)$, probably reflecting little more than recruit- ment of different nerve types by varying stimulation parameters. There is probably negligible tonic parasympathetic discharge because low spinal anesthesia (L5/S1) has little effect on sphincter tone.

Superimposed on the tonic state of the IAS is intermittent slow and ultraslow wave activity (10). Ultraslow wave activity is defined as discrete pressure fluctuations with a low frequency of around 1 to 2 cycles/min, and 10\% above and below baseline resting pressure. Slow wave activity occurs at a frequency of 15 to 35 cycles/min, with an amplitude of $5 \mathrm{mmHg}(11,12)$. The importance of these waves is not fully understood. They may act to counter rectal pressure waves (13) or may keep the anal canal empty and prevent desensitization of the anoderm (14). These waves are often deranged in patients with fecal incontinence (15), although it is not clear whether this is a marker of, or a contributor to, incontinence.

The rectoanal inhibitory reflex was first described by Gowers (16) in 1877. It is characterized by transient IAS relaxation in response to rectal distension, which brings the rectal contents into contact with the sensory epithelium of the anal canal, allowing discrimination of solid, liquid and gas. This process, known as anorectal sampling, is frequently abnormal in incontinent patients (17). Interestingly, this reflex is absent altogether in patients with Hirschsprung's disease, a condition characterized morphologically by a lack of myenteric ganglia in the distal colon and rectum (18). It is present, however, following sectioning of the hypogastric nerves, suggesting that the machinery necessary for the reflex is present entirely within the bowel wall and pelvic plexus (19).

\section{PHARMACOLOGICAL FEATURES}

Dale (20) originally classified the autonomic nervous system on the basis of neurotransmitter type. Nerves synthesizing and releasing acetylcholine, termed 'cholinergic nerves', are the predominant nerves that make up preganglionic efferent fibres of both the sympathetic and parasympathetic subdivisions. Acetylcholine acts at these autonomic ganglia through nicotinic receptors. Postganglionic parasympathetic fibres are also cholinergic, although acetylcholine released at the target tissue from these nerves acts via muscarinic receptors. Postganglionic sympathetic fibres release noradrenaline.

Many of the features of the IAS have been established in vitro using techniques such as the superfusion organ bath (21). IAS smooth muscle strips generate spontaneous myogenic tone after equilibration in vitro - a feature duplicated in other sphincteric smooth muscles. This tone is dependent on extracellular calcium and its entry via L-type calcium channels (22). IAS strips relax upon addition of carbachol (an acetylcholine analogue), an effect blocked by pretreatment with atropine, a muscarinic antagonist. By contrast, noradrenaline causes a dose-dependent contraction of muscle strips. Pretreatment with the alpha-blocker phentolamine unmasks a relaxation effect of noradrenaline, which is mediated via beta-receptors. Indeed, the beta- 
adrenergic agonist isoprenaline causes a relaxation in vitro. These fundamental pharmacological features of the IAS differ from the circular and longitudinal layers of the rectum, and the anal longitudinal muscle - evidence of 'sphincter specialization' of the IAS smooth muscle (23).

With appropriate parameters, electric field stimulation causes a relaxation of IAS strips that is blocked by tetrodotoxin, but not by atropine or guanethidine (24), confirming that the relaxation is nerve mediated, but neither cholinergic or adrenergic in nature. The search for this nonadrenergic noncholinergic transmitter led to several possibilities, including ATP (24), vasoactive intestinal peptide $(25,26)$ and carbon monoxide $(27)$.

O'Kelly et al (28) provided several convincing lines of evidence that nitric oxide was the most important nonadrenergic noncholinergic transmitter in the human IAS. Electric field stimulation of IAS strips was shown to cause a relaxation, which could be blocked by the addition of $\mathrm{N}$-nitro-L-arginine, a nitric oxide synthase inhibitor. This inhibition was reversed by the addition of an excess of $\mathrm{L}$-arginine, a nitric oxide precursor. There is also morphological evidence that nitric oxide is an important neurotransmitter in the IAS. Nitric oxide synthase-staining neurons have been demonstrated in the rectal myenteric plexus and anal canal by immunohistochemistry (29). This immunoreactivity was found to co-localize with wheat germ agglutinin conjugated to horseradish peroxidase after injection into the IAS in nerve tracer experiments (30). These findings further implied that nitric oxide might be responsible for mediating the rectoanal inhibitory reflex.

Finally, it has been shown that the relaxant effects of carbachol in vitro may be blocked not only by atropine, but also by nitric oxide synthase inhibitors (31). Similarly, it has been shown that the action of vasoactive intestinal peptide is dependent on nitric oxide synthesis (32). These nitrergic nerves presumably possess receptors for both acetylcholine and vasoactive intestinal peptide. This and other aspects of the pharmacology of the IAS are summarized in Figure 1.

\section{PHARMACOLOGICAL MANIPULATION}

\section{Agents to decrease IAS tone}

Of all aspects of clinical research of the IAS, agents to decrease IAS tone have been studied more than any others. This is because anal fissure, accounting for $10 \%$ of new outpatients in one study (33), has long been recognized to be associated with IAS spasm (34). Although this sphincter spasm may not be the cause of the acute fissure, it is probably central to the development of chronicity. The posterior commissure of the anal canal, an area that receives relatively few branches of the inferior rectal artery, is the most common site for anal fissures (35). With the level of IAS spasm seen in anal fissure, the perfusion index of the anoderm of this portion of the anal canal falls to 0.29 , a level that would produce rest pain in the lower limb (36). Lateral sphincterotomy produces a fall in anal canal pressure, with an associated rise in anodermal blood flow to levels seen in

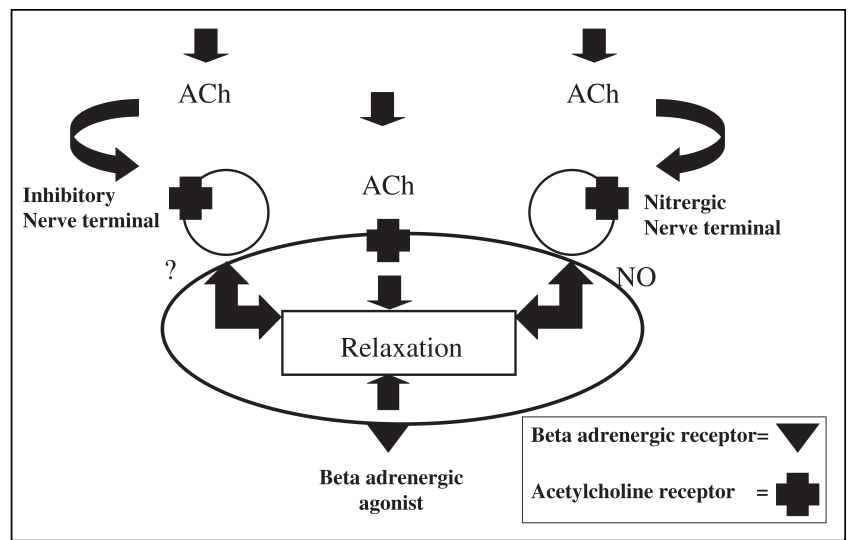

Figure 1) Summary of the pharmacology of the internal anal sphincter. The pharmacology of relaxation only is shown for clarity. Contraction occurs through the action of noradrenaline on alpha $a_{1}$-adrenoceptors. ACh Acetylcholine; NO Nitric oxide

controls (37). Sphincter spasm is not the only abnormality associated with anal fissure. Ultraslow waves have also been found more frequently in patients with fissures than in control subjects (38), and there is some evidence that these patients also have an abnormal rectoanal inhibitory reflex (39). The significance, if any, of these latter two observations is unknown.

Both lateral sphincterotomy and manual dilation of the anus produce fissure healing rates in excess of $90 \%$ (40). A drawback of surgery is an increased incidence of incontinence in the long term. Some centres have published surgical results combining good healing rates with negligible long term incontinence (41). Most series with long term follow-up, however, report rates of around 25\% for incontinence to flatus and/or solid stool $(42,43)$.

\section{Nitric oxide donors}

In 1990, before it was known that nitric oxide was an important neurotransmitter in this tissue, L'Hopital and coworkers (44) showed that sublingual glyceryl trinitrate (GTN) was effective in reducing IAS spasm. The first use of topical nitroglycerin to reduce anal canal pressure was by Guillemot and co-workers $(45,46)$ in normal and constipated patients. GTN and other exogenous nitrates are broken down by cellular metabolism to yield nitric oxide and effect IAS relaxation (47).

The Nottingham trial (48) was a randomized, prospective, double-blind, placebo controlled trial of $0.2 \%$ GTN paste in patients with chronic anal fissure. Eighty patients were recruited and instructed to apply the paste twice daily. Significant reductions in anal resting pressure and an increase in anodermal blood flow (measured by laser Doppler flowmetry) were observed in the treated group, but not in controls. At the end of eight weeks of treatment, healing was observed in $68 \%$ of treated patients but only $8 \%$ of controls - a finding that was highly significant. Headaches were reported by $58 \%$ of patients in the treatment arm, but by only $18 \%$ of those in the placebo group. The length of follow-up in this study was short, although a 
longer term assessment of these patients and those from another trial (49) (total 44 patients) were reported separately (50). At an average of 28 months' follow-up, 11 patients were found to have recurrent symptoms. Of these patients, three opted for sphincterotomy (two of whom had failed to heal on a second course of GTN), two healed spontaneously and the remaining six all healed with a second course of GTN.

Further trials in support of these findings followed. A randomized, prospective, double-blind, placebo controlled trial of $0.2 \%$ GTN paste for the treatment of chronic fissure was published a couple of years later (51), comprising 43 patients. The design was broadly similar to that in the Nottingham study (48), although treatment was given for only four weeks. Healing was observed in $46 \%$ of those taking the active treatment, compared with 16\% taking placebo, which was a significant difference. However, when eight patients with fissures after four weeks of GTN were reassessed at a mean of 28 months, five had relapsed. Bacher et al (52) reported results of a trial involving patients with acute or chronic fissures, who were randomly assigned to receive four weeks of treatment with either GTN paste or lignocaine gel. In this study comprising 35 patients, healing in the GTN treatment group was found to be $80 \%$ - significantly better than the $40 \%$ healing rates observed in the lignocaine treatment group. Healing was assessed by clinicians who were blinded to the patients' treatment. Carapeti et al (53), in a prospective, double-blind study, randomly assigned patients to three groups: placebo; $0.2 \%$ GTN three times daily; and $0.2 \% \mathrm{GTN}$, increasing every week by $0.1 \%$ to a maximum of $0.6 \%$. Only patients with chronic anal fissures were included, and treatment was given for eight weeks. Considering the two treatment groups together, healing was observed in $67 \%$ of treated patients compared with $32 \%$ of control subjects - a significant difference.

However, a recent prospective, randomized, multicentre study by Altomare et al (54) failed to demonstrate any significant difference in healing between patients with chronic anal fissure treated with four weeks of $0.2 \%$ GTN and those treated with placebo. The healing rate in the treatment group was $49 \%$, but this rate was less than the $52 \%$ healing rate observed in the placebo group. The healing rate of the group who received placebo was, therefore, more than six times that in the Nottingham trial (48), raising the obvious suggestion that the fissures themselves were substantially different. It is possible that more patients with acute fissures were included in the Italian study (54) because many of these fissures heal spontaneously. The less impressive healing rate in the group that received active treatment might be attributable to the short (four-week) treatment course used. After one month of therapy in the Nottingham trial (48), less than $20 \%$ of patients were healed.

A randomized, double-blind study compared $0 \%, 0.1 \%$, $0.2 \%$ and $0.4 \%$ GTN paste applied twice or three times daily for up to eight weeks. There was no significant difference in the rate of healing; the fissure healing rate was broadly similar, around $50 \%$ in each of the eight groups, containing 304 patients in total. Pain was more significantly reduced in the group that received the $0.4 \%$ GTN paste (55).

The latter two trials, in association with the poor healing rates seen in many unrandomized studies $(56,57)$, have tempered the initial enthusiasm engendered by GTN. Possible reasons for its lack of efficacy include its short duration of action (as little as $90 \mathrm{~min}$ in one study) (58), the incidence of headaches that may affect compliance (59) and tachyphylaxis (60).

Not surprisingly, two recent trials have compared GTN paste with sphincterotomy $(61,62)$. Both showed poor healing rates in the medically treated group, contrasting with high healing rates in the surgical group. Both trials claimed to have negligible rates of incontinence in the surgical group. However, follow-up to assess incontinence was performed only at six months or less in the two studies, which cannot be considered to have proved the safety of sphincterotomy. Anal canal pressures fall with age, and the surgeon does not know what further traumas, such as obstetric injury, await the sphincter in the future. It may often be many years before the damage of surgery is evident.

Other nitric oxide donors need to be evaluated, including isosorbide dinitrate (ISDN). ISDN itself may be responsible for the short term effects this drug, although its metabolite isosorbide mononitrate may be responsible for the longer term effects of lowering anal resting pressure. There have been two reports of the efficacy of ISDN in healing anal fissure $(63,64)$, although there is little compelling evidence that it is superior to GTN in terms of tolerability or efficacy. L-arginine was also proven to be effective at reducing mean anal resting pressure by around $40 \%$ in 10 volunteers (65). Further data are awaited.

GTN paste $(0.2 \%)$ has also been evaluated as an agent to reduce pain after hemorrhoidectomy (66). In a randomized, prospective, double-blind, placebo controlled trial, patients on active treatment had less pain, measured on a visual analogue score, although the difference was not significant. However, patients had less total and daily narcotic use, a difference that attained significance after the fourth postoperative day. Headaches were reported by eight of 15 patients who received the active treatment.

\section{Botulinum toxin}

Botulinum toxin has been used for a number of indications since the report of its first clinical use for strabismus in 1980 (67). Its initial use in the treatment of anorectal disease was reported in an open-label study of 12 patients with chronic anal fissure. Each received $5 \mathrm{U}$ of botulinum toxin into the external anal sphincter (68). After three months, 10 patients demonstrated healing.

In a prospective, double-blind, placebo controlled trial, 30 patients with chronic anal fissure were randomly assigned to receive either $20 \mathrm{U}$ of botulinum toxin or saline injection into the IAS (69). Both groups also received laxatives. After two months, the healing rate in the treatment 
group was $73 \%$, compared with $13 \%$ in the control group a statistically significant difference. The resting pressure in the treated group was significantly reduced by $25 \%$, while that in the placebo group was unaffected. Voluntary squeeze pressure was unaffected in both groups.

The optimal dose of botulinum toxin in anal fissure remains controversial. This is further complicated by the fact that doses are not equivalent between commercial preparations (70), even though units of botulinum toxin are related to the median lethal dose in mice. All doses of botulinum toxin in this review refer to Botox (Allergan, United Kingdom). However, even when one considers Botox alone, doses for anal fissure ranging between $2.5 \mathrm{U}$ (71) and $40 \mathrm{U}$ (72) have been employed. In terms of healing rate, better results are seen with $20 \mathrm{U}$ of botulinum toxin than with $15 \mathrm{U}$; there is also evidence that $25 \mathrm{U}$ is superior for retreatment (73). In another nonrandomized study, better healing rates were seen with $21 \mathrm{U}$ than with $10 \mathrm{U}$ or $15 \mathrm{U}$, although this difference did not reach statistical significance (74).

The optimal site of injection of botulinum toxin for anal fissure treatment is another unresolved area of controversy. The external anal sphincter (68), intersphincteric space (74) and IAS (73) have all been used. Certainly, injection into the IAS in the posterior midline appears to be superior to injection in the anterior midline, at least for posterior fissures (75).

Much of the inconsistency reflects uncertainty regarding the mechanism of action of botulinum toxin. The toxin appears to exert its effect on the IAS, reducing myogenic tone and blocking sympathetic nerves (76). Clinical trials are needed, however, to answer the separate question of where the site of injection should be for maximum efficacy and minimal side effects.

Results of a trial by Brisinda et al (77) suggested that botulinum toxin should be considered to be first-line therapy for anal fissure. In this trial, 50 patients were randomly assigned to either $20 \mathrm{U}$ of botulinum toxin into the IAS or $0.2 \%$ GTN paste for six weeks. Healing was found in $96 \%$ of patients treated with injection after two months, significantly superior to the $60 \%$ healing observed in those using the paste. All nine patients who had failed to heal with GTN treatment healed when retreated with botulinum toxin, suggesting that botulinum toxin, even if not considered first-line therapy, may be useful for refractory fissures. Lysy et al (78) support this suggestion, having shown, in patients with fissures failing to heal with ISDN as first-line therapy, that second-line treatment with botulinum toxin produces good healing rates. Botulinum toxin is even more effective if combined with further ISDN.

The reasons for the apparent superior efficacy of botulinum toxin over GTN are not known. As a single injection, the use of botulinum toxin circumvents any issues of patient compliance. Furthermore, although botulinum toxin's effects last only approximately three or four months, being reversed by the growth of new axon terminals (79), marked short term tachyphylaxis is not encountered in the same manner as seen with GTN. It will be many years before it is evident whether there are any long term sequelae of botulinum toxin use.

Botulinum toxin has also been injected into the external anal sphincter for the treatment of anismus $(80,81)$, although presumably it has little or no action on the IAS when used in this way.

\section{Calcium channel blockers}

Calcium is important to both the maintenance of IAS myogenic tone and the response of the IAS to agonists (82). Calcium channel blockers have been shown to reduce the mean anal resting pressure as oral (83), sublingual (84) and topical (85) preparations.

In a small, unrandomized study, 15 patients with chronic anal fissure were prescribed oral nifedipine retard $20 \mathrm{mg}$ twice daily, which was shown to reduce the mean anal resting pressure by $36 \%$. After eight weeks, fissure healing was seen in nine patients $(60 \%)$, and a further three patients (20\%) were asymptomatic (86).

In a prospective, randomized, double-blind trial, Antropoli et al (87) compared topical $0.2 \%$ nifedipine gel with $1 \%$ lidocaine $/ \%$ hydrocortisone in the treatment of acute anal fissure. Two hundred eighty-three patients were randomly assigned and treated for 21 days; all patients also received laxatives and an anal dilator. Mean anal resting pressures fell by $30 \%$ in the group that received nifedipine; squeeze pressure was also reduced by $17 \%$. Corresponding parameters in the lidocaine/hydrocortisone group were not reduced significantly. Fissure healing was seen in 95\% and $50 \%$ of patients, respectively. The authors did not observe any side effects. Topical diltiazem has also been employed in uncontrolled studies. A recent report of 71 patients, treated with $2 \%$ diltiazem ointment for a median of nine weeks, showed healing in $75 \%$ of patients (88). At longer term follow-up (median 32 weeks), approximately one-third of patients had recurrent symptoms, and half of these had clinical evidence of fissure relapse.

Calcium channel blockers have also been examined for acute, thrombosed, external hemorrhoids in a prospective, randomized, open-label study (89). Ninety patients were randomly assigned to receive either $0.3 \%$ nifedipine and $1.5 \%$ lidocaine, or $1.5 \%$ lidocaine alone. Total relief (defined as absence of pain and swelling) was observed in $92 \%$ of the group that received nifedipine group compared with $46 \%$ of controls after 14 days of therapy.

\section{Bethanechol paste}

Topical $0.1 \%$ bethanechol was shown to reduce maximum anal resting pressure by a mean of $24 \%$ in 10 normal volunteers studied, without side effects - an effect that lasted 3 to $5 \mathrm{~h}$ (85). In a small, open-label study, healing was observed in 10 of 15 patients with chronic anal fissure treated with $0.1 \%$ bethanechol applied three times daily for eight weeks. There were also significant reductions in resting pressures and pain scores, without side effects (90). Randomized, double-blind, placebo controlled studies of this agent are awaited. 


\section{Adrenoceptor modulators}

Pitt et al (91) studied the effects of a single $20 \mathrm{mg}$ dose of oral indoramin, an alpha $_{1}$-adrenoceptor blocker, in six healthy patients and seven patients with chronic anal fissure. They observed a fall in the mean anal resting pressure of $40 \%$ in the healthy subjects, and a fall of $36 \%$ after $1 \mathrm{~h}$ in those with fissure - an effect that was sustained for $3 \mathrm{~h}$. However, a subsequent randomized, placebo controlled trial examining the use of this agent in patients with anal fissure was abandoned early due to a lack of healing in the treatment arm. Only one of 14 patients in the treatment arm was healed after six weeks of therapy, and the fissure recurred in this patient within three months (92).

There is both in vivo (93) and in vitro (94) evidence to suggest that beta-receptors are upregulated in patients with anal fissure compared with controls. Beta-agonists have been shown to shorten the pain associated with proctalgia fugax (95), and have been shown to reduce the maximum anal resting pressure in both normal control subjects and patients with fissure (96). It is not clear whether the betaagonists will prove to be an effective treatment for fissure.

\section{AGENTS TO INCREASE IAS TONE}

In many patients with incontinence, a low anal resting pressure is observed on manometry. The IAS may be structurally intact or show anatomical disruption. In either case, surgery to correct isolated IAS problems has met with little success (97-99). There have been attempts to augment IAS function pharmacologically in this group.

\section{Phenylephrine}

In a study of 12 normal volunteers, an $8 \%$ rise in the maximum resting pressure was observed after treatment with 5\% phenylephrine, but a more impressive (and significant) $33 \%$ rise was observed after application of a $10 \%$ paste. This effect lasted for a median of $7 \mathrm{~h}$ and was not associated with side effects or a change in cardiovascular parameters (100).

A double-blind, random-order, placebo controlled, crossover trial examining the use of $10 \%$ phenylephrine gel to treat 12 patients with incontinence after ileoanal pouch construction was performed at St Mark's Hospital, London, United Kingdom (101). Six patients who received phenylephrine improved subjectively, compared with one patient who received placebo. Four patients had complete cessation of incontinence on the active treatment. Incontinence scores and maximum anal resting pressures were both significantly improved in the treatment group compared with those in the placebo group.

Less encouraging results were seen with 10\% phenylephrine gel in a similarly designed study of incontinent patients with ultrasonographically normal sphincters (102). Thirty-six patients (mean age 58 years) were recruited. The results showed no significant improvement in incontinence score, maximum anal resting pressures, or anodermal blood flow. Three patients also suffered a local dermatitis due to the paste. Six patients who received active treatment and two who received placebo, however, reported more than
$75 \%$ subjective improvement. Only a minority of patients with incontinence may be suitable for this therapy, and future work should seek to identify the characteristics of this group. Furthermore, the IAS from incontinent patients is known to be less responsive in vitro to both noradrenaline and electric field stimulation (103). Higher doses than those established in normal control subjects may be necessary for this group of patients.

This issue was addressed in a subsequent study of 10 patients, also with predominantly passive incontinence and structurally normal anal sphincters (104). Phenylephrine gel was applied in a double-blind manner at concentrations of $0 \%, 10 \%, 20 \%, 30 \%$ and $40 \%$, on separate days. All concentrations increased the maximum anal resting pressure relative to placebo, although the difference was significant only for the $30 \%$ and $40 \%$ concentrations; this effect was sustained for at least $2 \mathrm{~h}$. Effects on incontinence were not reported.

\section{Loperamide}

Loperamide has long been one of the mainstays of treatment for fecal incontinence (105). Its effects may not solely be to reduce the water content of the stool. It may also decrease the sensitivity of the rectoanal inhibitory reflex (106) and increase the tone of the anal sphincter (107), although this effect is probably not quantitatively important in vivo.

\section{AGENTS TO DECREASE IAS TONE INTERMITTENTLY AND APPROPRIATELY}

Defecatory problems may be attributable to many different causes. However, a small number are attributable to disordered function of the IAS. One example is megarectum. In patients with megarectum, the resting anal canal pressure may be normal, but the degree of relaxation of the IAS in response to a given volume of rectal distension is abnormal. The rectoanal inhibitory reflex is present but requires very large rectal distension volumes in order to be elicited (108).

Phosphodiesterase (PDE) inhibitors have recently been shown to mediate relaxation of the IAS in vitro (109). PDE inhibitors prevent the breakdown of intracellular cAMP and cGMP. Both cAMP and cGMP cause relaxation of the IAS (110). Eleven families of PDEs have been identified to date (111), many with specific inhibitors.

Sildenafil, a PDE-5 inhibitor, has recently been identified as a powerful drug for the treatment of impotence. One of its attractive features is that it has few effects on intracavernosal pressure in the absence of sexual arousal and penile nerve stimulation (112). Its efficacy comes from its ability to augment the vascular smooth muscle relaxation secondary to nitrergic nerve recruitment. Both the vascular smooth muscle underlying erection and the IAS use the nitric oxide/cGMP/PDE-5 pathway. Although speculative, sildenafil might prove to be useful for augmenting the intermittent and appropriate IAS relaxation. It is not known whether such pharmacological interventions would be widely applicable to the spectrum of problems of disordered 
defecation, although sildenafil has proved to be efficacious in the treatment of impotence secondary to a range of pathologies.

\section{CONCLUSIONS}

The use of pharmacological agents to manipulate IAS function is in its infancy. Most research into agents to lower IAS pressure has concentrated on the treatment of anal fissure. There has been very little investigation of other conditions that might be ameliorated, including hemorrhoidal disease. By contrast, agents to increase IAS tone have been targeted at incontinent patients, but early results have shown that only a proportion of such patients benefit. Patients with incontinence are a heterogeneous group, and IAS dysfunction is rarely the sole cause of dysfunction.

In the short term, science has benefited from this explosion of interest into the IAS, as the drive for new therapies spawns basic research into the physiology and pharmacology of this tissue. Surgeons and physicians, although not universally convinced of a long term future for pharmacological intervention, have received a timely reminder of the risks to continence inherent in surgery to the anorectum. The long term legacy of a pharmacological approach to benign anorectal disease remains uncertain.

\section{REFERENCES}

1. Gaskell WH. The Involuntary Nervous System. New York: Longman, 1920.

2. Langley JN. The Autonomic Nervous System. Cambridge: Heffer, 1921.

3. Frenckner B, Euler CV. Influence of pudendal block on the function of the anal sphincters. Gut 1978;19:1163-74.

4. Lestar B, Penninckx F, Kerremans R. The composition of anal basal pressure. An in vivo and in vitro study in man. Int J Colorectal Dis 1989;4:118-22.

5. Dickinson VA. Maintenance of anal continence: a review of pelvic floor physiology. Gut 1978;19:1163-74.

6. Frenckner B, Ihre T. Influence of the autonomic nerves on the internal anal sphincter in man. Gut 1976;17:306-12.

7. Gutierrez JG, von Shah AN. Autonomic control of the internal anal sphincter in man. In: Trappen G, ed. Fifth International Symposium on Gastrointestinal Motility. Leuven: Typoff Press, 1975:363-73.

8. Carlstedt A, Nordgren S, Fasth S, Appelgren L, Hulten L. Sympathetic nervous influence on the internal anal sphincter and rectum in man. Int J Colorectal Dis 1988;3:90-5.

9. Lubowski DZ, Nicholls RJ, Swash M, Jordan MJ. Neural control of internal anal sphincter function. Br J Surg 1987;74:668-70.

10. Sun WM, Read NW, Miner PB, Kerrigan DD, Donnelly TC. The role of transient internal sphincter relaxation in faecal incontinence. Int J Colorectal Dis 1990;5:31-6.

11. Bouchoucha M, Choufa T, Faye A, Berger A, Arsac M. Anal pressure waves in patients with irritable bowel syndrome. Dis Colon Rectum 1999;42:1487-96.

12. Devroede G. Function of the anorectum: defecation and continence. In: Phillips SF, Shorter RG, eds. The Large Intestine: Physiology, Pathophysiology and Disease. New York: Raven, 1991:115-40.

13. Sorensen SM, Gregersen H, Djurhuus JC. Spontaneous anorectal pressure activity: evidence of internal anal sphincter contractions in response to rectal pressure waves. Scand J Gastroenterol 1989;24:115-200.

14. Zbar AP, Jayne DG, Mathur D, Ambrose NS, Guillou PJ. The importance of the internal anal sphincter (IAS) in maintaining continence: anatomical, physiological and pharmacological considerations. Colorectal Dis 2000;2:193-202.

15. Sangwan YP, Coller JA, Schoetz DJ, Roberts PL, Murray JJ. Relationship between manometric anal waves and faecal incontinence. Dis Colon Rectum 1995;38:370-4.
16. Gowers WR. The automatic action of the sphincter ani. Proc R Soc Lond (Biol) 1877;26:77-84.

17. Miller R, Bartolo DC, Cervero F, Mortensen NJ. Anorectal sampling: a comparison of normal and incontinent patients. Br J Surg 1988;75:44-7.

18. O'Kelly TJ, Davies JR, Tam PK, Brading AF, Mortensen NJMcC. Abnormalities of nitric oxide producing neurons in Hirschsprung's disease: morphology and implications. J Paediatr Surg 1994;29:294-300.

19. Schuster MM, Hendrix TR, Mendeloff AI. The internal anal sphincter response: manometric studies on its normal physiology, neural pathways and alteration in bowel disorders. J Clin Invest 1963;42:196-207.

20. Dale HH. Nomenclature of fibres in the autonomic nervous system and their effects. J Physiol 1933;80:10-1.

21. Brading AF, Sibley GNA. A superfusion apparatus to study field stimulation of smooth muscle from mammalian urinary bladder. J Physiol 1983;334:11-4P.

22. Cook TA, Brading AF, Mortensen NJMcC. Differences in contractile properties of anorectal smooth muscle and the effects of calcium channel blockade. Br J Surg 1999;86:70-5.

23. O'Kelly TJ, Brading AF, Mortensen NJMcC. In vitro response of the human anal canal longitudinal muscle layer to cholinergic and adrenergic stimulation: evidence of sphincter specialization. Br J Surg 1993;80:1337-41.

24. Burleigh DE, D'Mello A, Parks AG. Responses of isolated human internal anal sphincter to drugs and electrical field stimulation. Gastroenterology 1979;77:484-90.

25. Lynn RB, Sankey SL, Chakder S, Rattan S. Co-localization of NADPH-diaphorase staining and VIP immunoreactivity in neurons in opossum internal anal sphincter. Dig Dis Sci 1995;40:781-91.

26. Nurko S, Dunn BM, Rattan S. Peptide histidine isoleucine and vasoactive intestinal polypeptide cause relaxation of opossum internal anal sphincter via two distinct receptors. Gastroenterology 1989;96:403-13.

27. Chakder S, Cao G-Y, Lynn RB, Rattan S. Heme oxygenase activity in internal anal sphincter: affects of nonadrenergic, noncholinergic nerve stimulation. Gastroenterology 2000;118:477-86.

28. O'Kelly TJ, Brading AF, Mortensen NJMcC. Nerve mediated relaxation of the human internal anal sphincter: the role of nitric oxide. Gut 1993;34:689-93.

29. O'Kelly TJ, Davies JR, Brading AF, Mortensen NJMcC. Distribution of nitric oxide synthase containing neurons in the rectal myenteric plexus and anal canal. Morphological evidence that nitric oxide mediates the rectoanal inhibitory reflex. Dis Colon Rectum 1994;37:350-7.

30. Stebbing JF, Brading AF, Mortensen NJMcC. Nitric oxide and the rectoanal inhibitory reflex: retrograde neuronal tracing reveals a descending nitrergic rectoanal pathway in a guinea pig model. Br J Surg 1996;83:493-8.

31. O'Kelly TJ, Brading AF, Mortensen NJMcC. Nitric oxide mediates cholinergic relaxation of human internal anal sphincter muscle in vitro. Gut 1992;33:A48. (Abst)

32. Chakder S, Rattan S. Evidence for VIP-induced increase in NO production in myenteric neurons of opossum internal anal sphincter. Am J Physiol 1996;270:G492-7.

33. Pescatori M, Interisano A. Annual report of the Italian coloproctology units. Tech Coloproctol 1995;3:29-30.

34. Brodie BC. Lectures on diseases of the rectum; lecture III; preternatural contraction of the sphincter ani. Lond Med Gaz $1835 ; 16: 26-31$.

35. Klosterhalfen B, Vogel P, Rixen H, Mittermayer C. Topography of the inferior rectal artery: a possible cause of chronic primary anal fissure. Dis Colon Rectum 1989;32:43-52.

36. Gibbons CP, Read NW. Anal hypertonia in fissures: cause or effect? Br J Surg 1986;73:443-5.

37. Schouten WR, Briel JW, Auwerda JJA, de Graaf EJR. Why do anal fissures heal after lateral anal sphincterotomy? Dis Colon Rectum 1995;37:P9.

38. Keck JO, Staniunas RJ, Coller JA, Barrett RC, Oster ME. Computergenerated profiles of the anal canal in patients with anal fissure. Dis Colon Rectum 1995;38:72-9.

39. Northmann BJ, Schuster MM. Internal anal sphincter derangement with anal fissures. Gastroenterology 1974;67:216-20.

40. Lund JN, Scholefield JH. Aetiology and treatment of anal fissure. Br J Surg 1996;83:1335-44. 
41. Strugnell NA, Cooke SG, Lucarotti ME, Thomson WH. Controlled digital anal dilatation under total neuromuscular blockade for chronic anal fissure: a justifiable procedure. Br J Surg 1999;86:651-5.

42. Snooks S, Henry MM, Swash M. Faecal incontinence after anal dilatation. Br J Surg 1984;71:617-8.

43. Khubchandani IT, Reed JF. Sequelae of internal sphincterotomy for chronic fissure-in-ano. Br J Surg 1989;76:431-4.

44. L'Hopital F, Michelland O, Lunaud B, Bommelaere G. Constipation et hypertonie du sphincter interne de l'anus: reponse sphincterienne a l'administration sub-linguale de $0.40 \mathrm{mg}$ de Natispray. Gastroenterol Clin Biol 1990;14:268.

45. Guillemot F, Lone YC, Leroi H, Lamblin MD, Cortot A. Nitroglycerin in situ reduces upper anal canal pressure. Dig Dis Sci 1992;37:155.

46. Guillemot F, Leroi H, Lone YC, Rousseau CG, Lamblin MD, Cortot A. Action of in situ nitroglycerin on upper anal canal pressure of patients with terminal constipation. A pilot study. Dis Colon Rectum 1993;36:372-6.

47. Fung HL. Clinical pharmacology of organic nitrates. Am J Cardiol 1993; 72:9C-13C.

48. Lund JN, Scholefield JH. A randomised, prospective, double-blind, placebo-controlled trial of glyceryl trinitrate ointment in the treatment of anal fissure. Lancet 1997;349:11-4.

49. Lund JN, Armitage NC, Scholefield JH. Use of glyceryl trinitrate ointment in the treatment of anal fissure. Br J Surg 1996;83:776-7.

50. Lund JN, Scholefield JH. Follow-up of patients with chronic anal fissure treated with topical glyceryl trinitrate. Lancet 1998;352:1681.

51. Kennedy ML, Sowter S, Nguyen H, Lubowski DZ. Glyceryl trinitrate ointment for the treatment of chronic anal fissure. Dis Colon Rectum 1999;42:1000-6.

52. Bacher H, Mischinger HJ, Werkgartner, et al. Local nitroglycerin for treatment of anal fissures: an alternative to lateral sphincterotomy? Dis Colon Rectum 1997;40:840-5.

53. Carapeti EA, Kamm MA, McDonald PJ, Chadwick SJD, Melville D, Phillips RKS. Randomised controlled trial shows that glyceryl trinitrate heals anal fissures, higher doses are not more effective, and there is a high recurrence rate. Gut 1999;44:727-30.

54. Altomare DF, Rinaldi M, Milito G, et al. Glyceryl trinitrate for chronic anal fissure - healing or headache? Results of a multicenter, randomised, placebo-controlled, double-blind trial. Dis Colon Rectum 2000;43:174-9.

55. Beck D, Rafferty J, Yee L, Binderow S, and Fissure Study Group. A study to determine the nitroglycerin ointment dose and dosing interval that best promote the complete healing of chronic anal fissures. Dis Colon Rectum 2000;43:A35. (Abst)

56. Dorfmann G, Levitt M, Platell C. Treatment of chronic anal fissure with topical glyceryl trinitrate. Dis Colon Rectum 1999;42:1007-10.

57. Hasegawa H, Radley S, Morton DG, Dorricott NJ, Campbell DJ, Keighley MR. Audit of topical glyceryl trinitrate for treatment of fissure-in-ano. Ann R Coll Surg Engl 2000;82:27-30.

58. Jonas M, Wright J, Neal K, Scholefield J. Topical $0.2 \%$ glyceryl trinitrate ointment has a short-lived effect on resting anal pressure. Dis Colon Rectum 2000;43:A38. (Abst)

59. Hyman NH, Cataldo PA. Nitroglycerin ointment for anal fissures: effective treatment or just a headache? Dis Colon Rectum 1999;42:383-5.

60. Watson SJ, Kamm MA, Nicholls RJ, Phillips RKS. Topical glyceryl trinitrate in the treatment of chronic anal fissure. Br J Surg 1996;83:771-5.

61. Evans J, Luck A, Hewett P. Glyceryl trinitrate vs lateral sphincterotomy for chronic anal fissure. Prospective randomized trial. Dis Colon Rectum 2001;44:93-7.

62. Richard CS, Gregoire R, Plewes EA, et al. Internal sphincterotomy is superior to topical nitroglycerin in the treatment of chronic anal fissure. Dis Colon Rectum 2000;43:1048-58.

63. Schouten WR, Briel JW, Boerma MO, Auwerda JJA, Wilms EB, Graatsma BH. Pathophysiological aspects and clinical outcome of intra-anal application of isorbide dinitrate in patients with chronic anal fissure. Gut 1996;39:465-9.

64. Lysy J, Israelit-Yatzkan Y, Sestiere-Ittah M, Keret D, Goldin E. Treatment of chronic anal fissure with isosorbide dinitrate: long term results and dose determination. Dis Colon Rectum 1998;41:1406-10.

65. Schouten W, Zimmermann D, Briel J, Hechtmann H. Effects of L-arginine on resting anal pressure. Dis Colon Rectum 2000;43:A2. (Abst)
66. Wasvary H, Hain J, Barkel D, Klein S. Randomized, prospective, double-blind, placebo-controlled trial of effect of nitroglycerin ointment on pain after haemorrhoidectomy. Dis Colon Rectum 2000;43:A33. (Abst)

67. Scott AB. Botulinum toxin injection into extraocular muscles as an alternative to strabismus surgery. Ophthalmology 1980;87:1044-9.

68. Jost WH, Schimrigk K. Therapy of anal fissure using botulin toxin. Dis Colon Rectum 1994;37:1321-4.

69. Maria G, Cassetta E, Gui D, Brisinda G, Bentivoglio AR Albanese A. A comparison of botulinum toxin and saline for the treatment of chronic anal fissure. N Engl J Med 1998;338:217-20.

70. Jost WH. One hundred cases of anal fissure treated with botulin toxin: early and long term results. Dis Colon Rectum 1997;40:1029-32.

71. Fernandez-Lopez F, Conde Freire R, Rios Rios A, Garcia Iglesias J, Cainzos Fernandez M, Potel Lesquereux J. Botulinum toxin for the treatment of anal fissure. Dig Surg 1999;16:515-8.

72. Madalinski M. Botox and Dysport are distinct. Endoscopy 2000;32:502-3

73. Maria G, Brsinda G, Bentivoglio AR, Cassetta E, Gui D, Albanese A. Botulinum toxin injections in the internal anal sphincter for the treatment of chronic anal fissure: long term results after two different treatment regimes. Ann Surg 1998;228:664-9.

74. Minguez M, Melo M, Espi A, et al. Therapeutic effects of different doses of botulinum toxin in chronic anal fissure. Dis Colon Rectum 1999;42:1016-21.

75. Maria G, Brisinda G, Bentivoglio AR, Cassetta E, Gui D, Albanese A. Influence of botulinum toxin site of injections on healing rate in patients with chronic anal fissure. Am J Surg 2000;179:46-50.

76. Jones OM, Moore JA, Brading AF, Mortensen NJMcC. The site and mechanism of action of botulinum toxin porcine anal sphincter Colorectal Dis. (Abst) (In press)

77. Brisinda G, Maria G, Bentivoglio AR, Cassetta E, Gui D, Albanese A. A comparison of injections of botulinum toxin and topical nitroglycerin ointment for the treatment of chronic anal fissure. N Engl J Med 1999;341:65-9.

78. Lysy J, Israelit-Yatzkan Y, Sestiery-Ittah M, Weksler-Zangen S, Keret D, Goldin E. Topical nitrates potentiate the effects of botulinum toxin in the treatment of patients with refractory anal fissure. Gut 2001;48:221-4.

79. Borodic GE, Ferrante RJ, Pearce LB, Alderson K. Pharmacology and histology of the therapeutic applications of botulinum toxin. In: Jankovic J, Hallett M, eds. Therapy with Botulinum Toxin. New York: Marcel Dekker, 1994:119-57.

80. Joo JS, Agachan F, Wolff B, Nogueras JJ, Wexner SD. Initial North American experience with botulinum toxin type A for treatment of anismus. Dis Colon Rectum 1996;39:1107-11.

81. Shafik A, El-Sibai O. Botulin toxin in the treatment of non-relaxing puborectalis syndrome. Dig Surg 1998;15:347-51.

82. Cook TA, Brading AF, Mortensen NJMcC. Effects of nifedipine on anorectal smooth muscle in vitro. Dis Colon Rectum 1999;42:782-7.

83. Jonard P, Essamri B. Diltiazem and internal anal sphincter. Lancet 1987;i:754.

84. Chrysos E, Xynos E, Tzovaras G, Zoras OJ, Tsiaoussis J, Vassilakis SJ. Effect of nifedipine on rectoanal motility. Dis Colon Rectum 1996;39:212-6.

85. Carapeti EA, Kamm MA, Evans BK, Phillips RKS. Topical diltiazem and bethanechol decrease anal sphincter pressure without side effects. Gut 1999;45:719-22.

86. Cook TA, Humphreys MM, Mortensen NJMcC. Oral nifedipine reduces resting anal pressure and heals chronic anal fissures. Br J Surg 1999;86:1269-73.

87. Antropoli C, Perrotti P, Rubino M, et al. Nifedipine for local use in conservative treatment of anal fissures: preliminary results of a multicenter study. Dis Colon Rectum 1999;42:1011-5.

88. Knight JS, Birks M, Farouk R. Topical diltiazem ointment in the treatment of chronic anal fissure. Br J Surg 2001;88:553-6.

89. Perrotti P, Antropoli C, Molino D, De Stefano G, Antropoli M. Conservative treatment of acute thrombosed external haemorrhoids with topical nifedipine. Dis Colon Rectum 2001;44:405-9.

90. Carapeti EA, Kamm MA, Phillips RKS. Topical diltiazem and bethanechol decrease anal sphincter pressure and heal anal fissures without side effects. Dis Colon Rectum 2000;43:1359-62.

91. Pitt J, Craggs MM, Henry MH, Boulos PB. Alpha-1 adrenoceptor blockade: potential new treatment for anal fissures. Dis Colon Rectum 2000;43:800-3. 
92. Pitt J, Dawson P, Hallan R, Boulos P. Double-blind, randomised, placebo-controlled trial of oral indoramin to treat chronic anal fissure. Dis Colon Rectum 2000;43:A32. (Abst)

93. Ojo-Aromokudo O, Pitt J, Boulos PB, Knight SL, Craggs MD. A comparison of alpha and beta adrenoceptor function of the internal anal sphincter in people with and without chronic anal fissures. J Physiol 1998;507:19P.

94. Regadas FS, Batista LK, Albuquerque JL, Capaz FR. Pharmacological study of the internal anal sphincter in patients with chronic anal fissure. Br J Surg 1993;80:799-801.

95. Eckhardt VF, Dodt O, Kanzler G, Bernhard G. Treatment of proctalgia fugax with salbutamol inhalation. Am J Gastroenterol 1996;91:686-9.

96. Pitt J, Henry MM, Craggs MD, Boulos PB. A potential new medical therapy for chronic anal fissure. Int J Colorectal Dis 1997;12:169.

97. Leroi AM, Kamm MA, Weber J, Denis P, Hawley PR. Internal anal sphincter repair. Int J Colorectal Dis 1997;12:243-5.

98. Deen KI, Kumar D, Williams JG, Grant EA, Keighley MRB. Randomized trial of internal anal sphincter plication with pelvic floor repair for neuropathic fecal incontinence. Dis Colon Rectum 1995;38:14-8.

99. Morgan AR, Patel B, Beynon J, Carr ND. Surgical management of anorectal incontinence due to internal anal sphincter deficiency. Br J Surg 1997;84:226-30.

100. Carapeti EA, Kamm MA, Evans BK, Phillips RKS. Topical phenylephrine increases anal sphincter resting pressure. Br J Surg 1999;86:267-70.

101. Carapeti EA, Kamm MA, Nicholls RJ, Phillips RKS. Randomized, controlled trial of topical phenylephrine for faecal incontinence in patients after ileoanal pouch construction. Dis Colon Rectum 2000;43:1059-63.
102. Carapeti EA, Kamm MA, Phillips RKS. Randomized controlled trial of topical phenylephrine in the treatment of faecal incontinence. Br J Surg 2000;87:38-42.

103. Speakman CT, Hoyle CH, Kamm MA, Henry MM, Nicholls RJ, Burnstock G. Adrenergic control of the internal anal sphincter is abnormal in patients with idiopathic faecal incontinence. Br J Surg 1990;77:1342-4.

104. Cheetham MJ, Kamm MA, Phillips RKS. Topical phenylephrine increases anal canal resting pressure in patients with faecal incontinence. Gut 2001;48:356-9.

105. Hallgren T, Fasth S, Delbro DS, Nordgren S, Oresland T, Hulten L. Loperamide improves anal sphincter function and continence after restorative proctocolectomy. Dig Dis Sci 1994;39:2612-8.

106. Goke M, Ewe K, Donner K, Meyer zum Buschenfelde KH. Influence of loperamide and loperamide oxide on the anal sphincter. A manometric study. Dis Colon Rectum 1992;35:857-61.

107. Musial F, Enck P, Kalveram KT, Erckenbrecht JF. The effect of loperamide on anorectal function in normal healthy men. J Clin Gastroenterol 1992;15:321-4.

108. Gattuso JM, Kamm MA. Clinical features of idiopathic megarectum and idiopathic megacolon. Gut 1997;41:93-9.

109. Jones OM, Brading AF, Mortensen NJMcC. Phosphodiesterase inhibitors cause relaxation of the internal anal sphincter in vitro. A novel treatment for anal fissure? Dis Colon Rectum. (In press)

110. VanderWall, Bealer JF, Adzick NS, Harrison MR. Cyclic GMP relaxes the internal anal sphincter in Hirschsprung's disease. J Paediatr Surg 1998;23:45-8.

111. Fawcett L, Baxendale R, Stacey P, et al. Molecular cloning and characterization of a distinct human phosphodiesterase gene family: PDE 11A. Proc Natl Acad Sci USA 2000;97:3702-7.

112. Goldberg MM. Safety and efficacy of sildenafil citrate in the treatment of male erectile dysfunction. Clin Ther 1998;20:1033-48. 


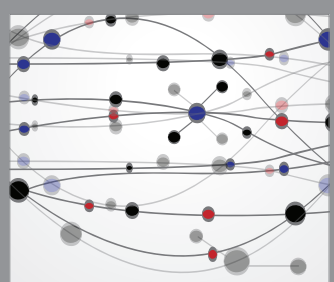

The Scientific World Journal
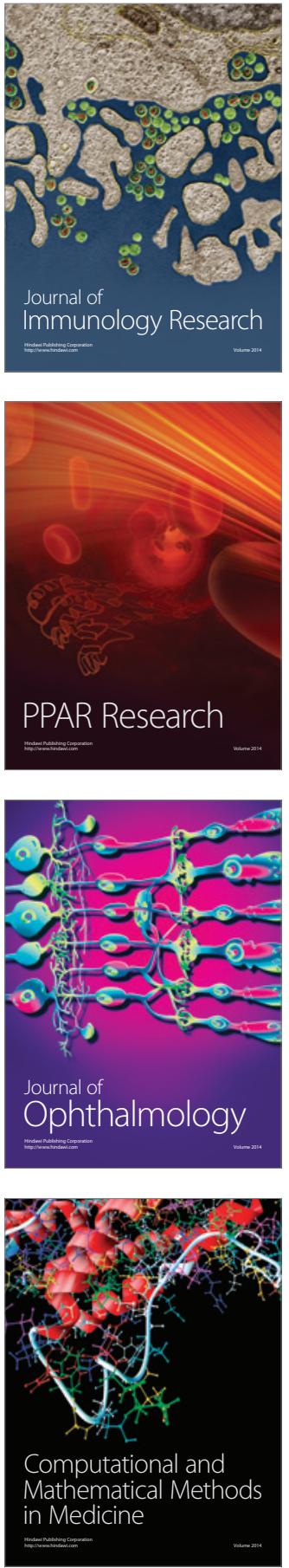

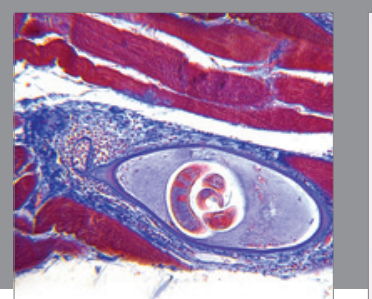

Gastroenterology Research and Practice

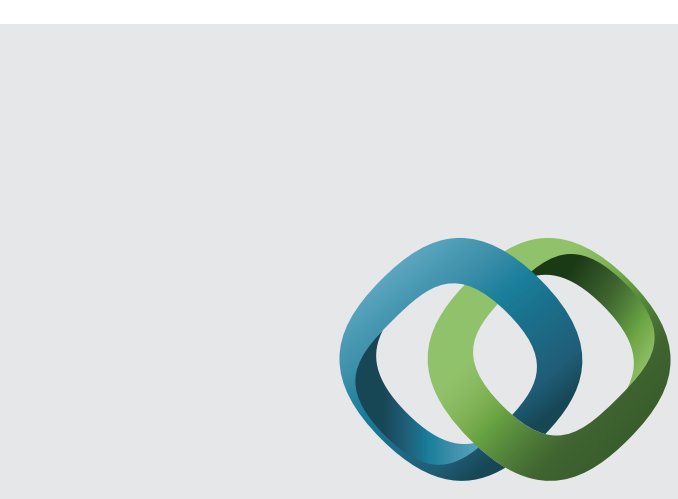

\section{Hindawi}

Submit your manuscripts at

http://www.hindawi.com
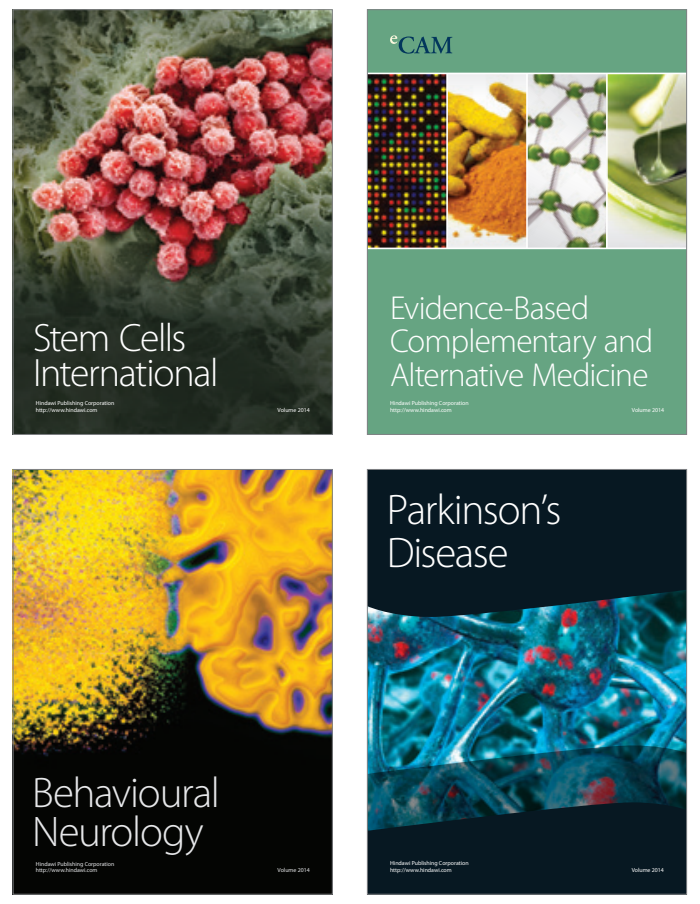
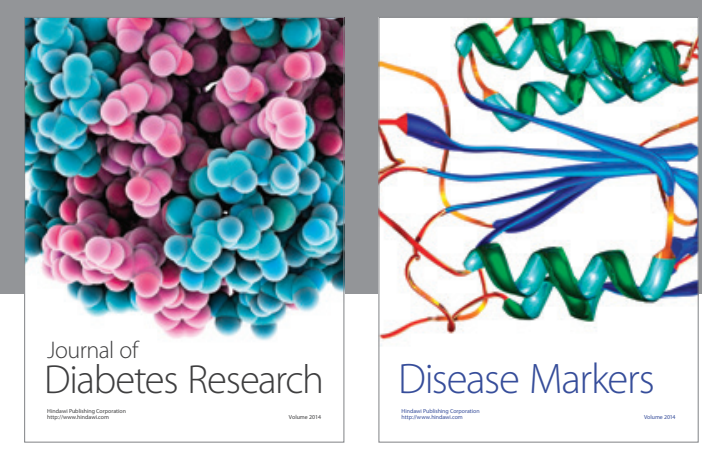

Disease Markers
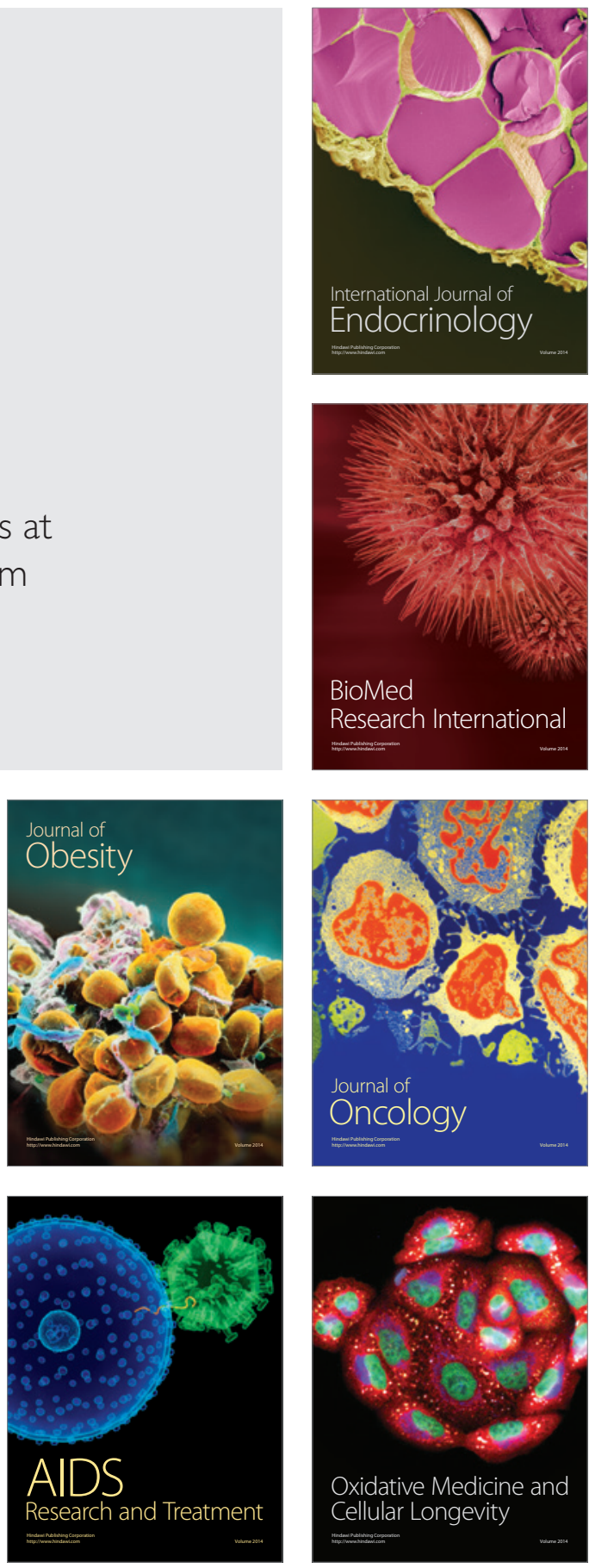